\title{
Immunomodulatory efficiency of Etroplus suratensis muscle protein
}

\author{
PALLVARNANATHASAMY DHASARATHAN ${ }^{1}$, P. PARTHASARATHY ${ }^{2}$, D. JENILARANI \\ NEELAM JAISWAL ${ }^{4}$ \\ ${ }^{1}$ Prathyusah Institute of Technology and Management, Thiruvallur, India \\ ${ }^{2}$ Department of Biotechnology, Rajalakshmi Engineering College, Chennai, India \\ ${ }^{3}$ Department of Biotechnology, Prathyusha Institute of Technology and Management, Thiruvallur, India \\ ${ }^{4}$ Department of Biotechnology, Uniwersity of Mumbai, India
}

\begin{abstract}
The protein extract of Etroplus suratensis (E. suratensis) collected from Bavanisagar dam was found to be effective against all tested organisms with an inhibition zone ranging from 0.2 to $1.9 \mathrm{~mm}$. When the result was compared with standard antibiotic Streptomycin, a moderate efficiency was observed. In vitro, an antibacterial assay was used to assess the efficacy of fish protein in inhibiting the growth of pathogenic microbes. The fish protein of E. suratensis collected from Bavanisagar had a broad spectrum of antibacterial potential. The minimal inhibitory concentrations of E. suratensis against pathogens are the highest in protein collected from Bavanisagar. In the fish protein collected from Bavanisagar, it has been shown that the minimum bactericidal concentration $(M B C)$ value is higher in Bacillus subtilis $(0.85 / 20 \mu \mathrm{g} / \mathrm{ml})$ and the lowest in Micrococcus $(0.1 / 100 \mu \mathrm{g} / \mathrm{ml})$. The sub-lethal dose of fish protein was estimated at $1 / 10$ of $96 \mathrm{~h} \mathrm{LD50}$ dose $(30 \mu \mathrm{g} / \mathrm{ml} / \mathrm{Kg})$, the antibody response was significantly enhanced on day 14 and day $21(p<0.01)$. The highest IgG level was noticed on day 21, which decreased towards day 28. This result showed the antibody production with an increased $\operatorname{Ig} G$ concentration. The above results demonstrate that fish protein extracts have great potential as immunostimulants against the microorganisms and they can be used in the treatment of infectious diseases caused by the microorganisms.
\end{abstract}

Key words: muscle, protein, suratensis.

(Centr Eur J Immunol 2014; 39 (1): 30-35)

\section{Introduction}

Fish live in an environment rich in microorganisms. They are vulnerable to be invaded by pathogenic or opportunistic micro-organisms. Compounds with broad antimicrobial activities are important for fish as their adaptive immune system is structurally simpler than that of mammals or amphibians, and is not fully effective in young fry or at low environmental temperature [1]. An immunostimulant triggers increased immune activity. Some, such as vaccines, target particular proteins; these are termed specific immunostimulants. Others are nonspecific and work on the immune system as a whole or general system within it to increase the immune response. The body produces a number of these compounds naturally and they are also produced in synthetic settings and by some natural organisms. The immunostimulants mainly facilitate the function of phagocytic cells, increase their bactericidal activities, and stimulate the natural killer cells, complement system, lysozyme activity, and antibody responses in fish and shellfish which confer enhanced protection against infectious diseases. Substances such as levamisole and glucan, peptidoglycan, chitin, chitosan, yeast and vitamin combinations as well as various products derived from plants and animals are effective in prevention of disease. In light of the above developments in the field of aquaculture, this work aims to isolate and characterize bioactive potential and immunomodulator efficiency of muscle protein of Etroplus suratensis.

Several compounds have been extracted from fish and employed as remedies in the medical field. According to Manjula et al. (2011) [2], one of the most promising discoveries of the 1990s was the discovery of a new chemical compound derived from dogfish shark (Squalus acanthias). It is reported to kill parasites, fungi and bacteria. Some of the compounds isolated from fish are important tools for biochemical research or as new leads for the development of anticancer and antiviral drugs. In the present investigation, muscle protein isolated from E. suratensis collected from Bavanisagar dam was screened for antimicrobial activity and immunomodulatory potential. 


\section{Material and methods}

One gram of muscle sample was taken from E. suratensis collected from Bavanisagar dam $\left(11^{\circ} 00^{\prime} \mathrm{N}, 77^{\circ} 00^{\prime} \mathrm{E}\right.$ Coimbatore, Tamilnadu, India). It was homogenized with distilled water using mortar and pestle for preparation of the crude sample. The crude sample protein content was extracted using centrifugation. For purposes of the in vivo study, the crude sample of muscle protein was injected into Swiss albino mice for production of primary antibody. The primary antibody was used as an immunizing agent. It was injected into rabbits to produce the secondary antibody. The secondary antibodies are labeled with horseradish peroxidase enzyme (HRP) for immunodetection.

For in vitro analysis, the crude protein sample was analysed by thin layer chromatography and isolated by the ion exchange chromatography method. The isolated protein was characterized by western blot [3]. From the crude protein sample, proteins were separated by the ion exchange chromatography method [3]. Before beginning the separation, an equilibration buffer was pumped through the column to equilibrate the oppositely charged ions. Upon injection of the crude protein sample, solute molecules were exchanged with the buffer ions as each ion would compete for the binding sites on the resin. The most weakly charged compounds eluted first, followed by those with successively stronger charges using elution buffer. The eluted protein sample purity was confirmed by the western blot method [3].

Western blot technique: Western blotting identifies with specific antibodies, proteins that have been separated from one another according to their size by gel electrophoresis. These techniques viz. SDS polyacrylamide gel electrophoresis, electroblotting and immunodetection together are used as powerful tools in biological studies [3].

Screening of antibacterial activity of protein: Antimicrobial activity of eluted muscle protein from $E$. suratensis samples collected from Tamirabarani river, Bavanisagar dam and Vembanad lake were screened using the disc diffusion method [4]. The Mueller Hinton agar medium was prepared. 24-hour culture of the organisms (Escherichia coli, Pseudomonas aeruginosa, Proteus vulgaris, Klebsiella pneumoniae, Citrobacter sp., Serratia marcescens, Micrococcus sp., Staphylococcus aureus and Bacillus subtilis) was spread evenly over the surface of the agar plates. Sterilized Whatman filter No. 1 discs thoroughly moistened with different concentrations (20, 40, 60, 80 and $100 \mu \mathrm{g} / \mathrm{ml}$ ) of eluted protein samples were placed on the surface of the plate. Discs moistened with sterile water were used as controls. The plates were incubated at $37^{\circ} \mathrm{C}$ for 24 hours. After the incubation period the plates were read. The size of the zone was measured and interpreted using the standard chart [2].

Minimum inhibitory concentration (MIC) and minimum bactericidal concentration (MBC) test: Min- imum inhibitory concentration (MIC) of the fish protein isolated from $E$. suratensis was determined from the culture plates that had the lowest concentrations and prevented the growth of bacterial strain. Minimum bactericidal concentration (MBC) was determined using the method of Samy and Ignacimuthu [5]. The fish proteins isolated from $E$. suratensis were diluted to obtain concentrations ranging from $10 \mu \mathrm{g}$ to $100 \mu \mathrm{g} / \mathrm{ml}$. A test tube containing $3 \mathrm{ml}$ of Muller Hinton broth and $0.1 \mathrm{ml}$ of bacterial suspension and $0.1 \mathrm{ml}$ of fish protein was incubated at $37^{\circ} \mathrm{C}$ for $24 \mathrm{~h}$. Bacterial turbidity was measured at $650 \mathrm{~nm}$ to determine bacterial inhibition. Streptomycin at $20 \mu \mathrm{g} / \mathrm{ml}$ and $40 \mu \mathrm{g} / \mathrm{ml}$ was used as a positive control for determination of minimum bactericidal concentrations. The tubes containing only the growth medium and each of the bacterial strains were used as a negative control. The minimum bactericidal concentration that showed the reduction of the bacterial growth was measured from the turbidity of the culture assay optical density value. The average of three values was taken as the total number of colony forming bacterial suspensions [6].

Lethal dose analysis of isolated protein in fish, E. suratensis: Using a standard toxicological test [4] $\mathrm{LD}_{50}$ doses for the extracted protein was found out. From the $\mathrm{LD}_{50}$ doses, sub-lethal concentrations were derived for test substance (fish protein isolated from E. suratensis) for further experiments. The sub-lethal dose of substance was dissolved in water and was injected into the fish (Bavanisagar dam). The booster dose was renewed after three days.

Evaluation of immunomodulation: Two groups of experimental fish were maintained. One group of fish was immunized with $0.2 \mathrm{ml}(300 \mathrm{ppm})$ of fish protein (isolated from $E$. suratensis) through an intra-peritoneal injection using $1 \mathrm{ml}$ glass syringe with 24 gauge needle. The fish was held with lateral side facing towards the investigator. The needle was inserted about half a centimeter just above the peritoneal cavity (can be confirmed by the free movement of the free end). Another group of fish used as controls were given the same amount of saline. After two weeks all the fish including the control group were challenged with heat killed Aphanomyces invadans intra-peritoneally [7].

Blood was collected from the fish using $1 \mathrm{ml}$ tuberculin syringe with 24 gauge needle from the common cardinal vein situated just below the gills at a regular interval of seven days for antibody response till the $28^{\text {th }}$ day and at an interval of 2 days for lysozyme and neutrophil assay till the $10^{\text {th }}$ day. For bleeding, the fish was held in the left hand with the right side of the fish facing towards the investigator. The operculum was lifted and kept open by the left hand thumb. A metal rod $(3 \mathrm{~mm}$ diameter and $12 \mathrm{~cm}$ long) was used to lift the gill lamellae in order to expose the common cardinal vein. From the common cardinal vein nearly $0.2-0.3 \mathrm{ml}$ of blood was collected from each fish using $1 \mathrm{ml}$ glass tuberculin syringe fitted with 24 gauge 
needle. The whole procedure from the handling of the fish to the end of the bleeding process took only 30-40 seconds causing minimal trauma to the fish. Quick and gentle handling of fish is required to avoid stress which is known to suppress the immune system. Antigen administration and serial bleeding were always done between 14 hours and 16 hours to avoid possible influence of cardiac rhythmic variation on the immune response. The blood drawn was collected in Eppendorf tubes. Blood collected from immunized and normal fish was kept at room temperature for 15 minutes. The clot was freed from the wall of the microcentrifuge tube for efficient retraction and kept overnight at $4{ }^{\circ} \mathrm{C}$. The serum was separated by spinning down the clot at 3000 rpm for 15-20 minutes and collected in sterilized vials. The serum was stored in the freezer at $-20^{\circ} \mathrm{C}$ until further use [8].

Antibody titration: Antibody titration was performed in 96 well microtitre plates. $25 \mu \mathrm{l}$ of saline was added to all the wells. $25 \mu \mathrm{l}$ of serum was added to the first well and mixed well. From the first well, $25 \mu$ of the contents was transferred to the second well, i.e. two fold dilution was made up to the eleventh well. A volume of $25 \mu \mathrm{l}$ of heat killed bacterial cell suspension pre-stained with crystal violet was added to each well. The microtitre plate was hand shaken for effective mixing and incubated overnight at $35^{\circ} \mathrm{C}$. The highest dilution of the serum sample which showed detectable macroscopic agglutination was recorded and expressed as $\log _{2} 2$ antibody titer of the serum.

Table 1. Proteins isolated from E. suratensis collected from Bavanisagar dam by TLC method

\begin{tabular}{ccc}
\hline Sample No. & Character & E. suratensis protein \\
\hline 1. & RF value & 0.9 c.m \\
\hline 2. & no. of spots & 3 \\
\hline 3. & pigmentation & dark brow \\
\hline
\end{tabular}

Determination of immunoglobulin G (IgG) concentration: The protein A column was washed using $1 \mathrm{ml}$ of $1 \mathrm{X}$ equilibration buffer and the flow rate was adjusted to $<0.25 \mathrm{ml} /$ minute. The serum with equal volume of equilibration buffer was added to the column. $500 \mu$ of equilibration buffer was passed through the column and discarded, $1 \mathrm{ml}$ of elution buffer was added to the column and elute containing IgG was collected in the tube containing neutralizing buffer $(25 \mu \mathrm{l} / \mathrm{ml})$. This process was repeated 2-3 times. The optical density of the eluted sample was observed at $280 \mathrm{~nm}$ [8].

\section{Results and discussion}

The protein obtained from E. suratensis collected from Bavanisagar dam was screened by the thin layer chromatography method and recorded (Table 1). Four spots were detected in the sample. The Rf value of 2.9 was obtained for the Bavanisagar sample. Ion exchange chromatography was performed and the protein separated by the procedure was used for western blot analysis. The isolated protein was purified using enzymes such as DNAase and RNAase and purified the protein. The protein sample was isolated and characterized by the western blot method. $35 \mathrm{~K} \mathrm{Da}$ proteins were found to be abundant in fish. A thin band of $116 \mathrm{~K}$ Da was also found in the sample. The $35 \mathrm{~K}$ Da protein was isolated and injected into the fish E. suratensis. The $35 \mathrm{~K} \mathrm{Da}$ protein isolated from fish was injected into the experimental fish.

The study of the antibacterial activity of fish protein (E. suratense) collected from Bavanisagar is given in Table 2 . The concentration of the protein samples varied from $20 \mu \mathrm{g} / \mathrm{ml}$ to $100 \mu \mathrm{g} / \mathrm{ml}$. The maximum inhibitory concentration was observed in $100 \mu \mathrm{g} / \mathrm{ml}$ samples. Among the various bacteria tested, maximum antibacterial effect was exhibited against Citrobacter sp. and the minimum value was obtained against Staphylococcus aureus.

Table 2. Antibacterial effect of fish protein collected from Bavanisagar E. suratensis samples against pathogenic bacteria

\begin{tabular}{|c|c|c|c|c|c|c|}
\hline \multirow{2}{*}{$\begin{array}{l}\text { Sample } \\
\text { No. }\end{array}$} & \multirow{2}{*}{$\begin{array}{c}\text { Bacterial culture } \\
\text { (inhibition zone in } \mathbf{~ m m} \text { ) }\end{array}$} & \multicolumn{5}{|c|}{ Protein concentration $(\mu \mathrm{g} / \mathrm{ml})$} \\
\hline & & 20 & 40 & 60 & 80 & 100 \\
\hline 1 & Escherichia coli & 6 & 8 & 18 & 25 & 28 \\
\hline 2 & Pseudomonas aeruginosa & 6 & 7 & 12 & 18 & 24 \\
\hline 3 & Proteus vulgaris & 8 & 9 & 18 & 23 & 30 \\
\hline 4 & Klebsiella pneumonia & 7 & 9 & 18 & 23 & 27 \\
\hline 5 & Citrobacter sp. & 9 & 12 & 15 & 26 & 32 \\
\hline 6 & Serratia marcescens & 9 & 15 & 18 & 25 & 26 \\
\hline 7 & Micrococcus sp. & 9 & 12 & 15 & 21 & 23 \\
\hline 8 & Staphylococcus aureus & 6 & 9 & 13 & 18 & 21 \\
\hline 9 & Bacillus subtilis & 4 & 6 & 9 & 17 & 23 \\
\hline
\end{tabular}


The minimal inhibitory concentrations of E. suratensis against pathogens are the highest for protein of E. suratensis samples collected from Bavanisagar. Bavanisagar fish protein sample was tested against the nine different pathogens. The concentration of the extracts was $20,40,60,80$ and $100 \mu \mathrm{g} / \mathrm{ml}$. In addition, Streptomycin at $50 \mu \mathrm{g} / \mathrm{ml}$ and $100 \mu \mathrm{g} / \mathrm{ml}$ was used as controls. The minimum bactericidal concentration of protein isolated from E. suratensis samples against pathogenic bacteria is given in Table 3 . The bactericidal concentration of fish protein at $100 \mu \mathrm{g} / \mathrm{ml}$ as higher than the concentration of Streptomycin at $50 \mu \mathrm{g} / \mathrm{ml}$ against $P$. vulgaris. Of the Bavanisagar E. suratensis fish protein samples tested, the highest bactericidal activity was observed in the fish extracts of $100 \mu \mathrm{g} / \mathrm{ml}$ concentrations.

In vitro antibacterial assay used to assess the efficacy of fish protein, E. suratensis, to inhibit the growth of pathogenic microbes showed that a sample of fish protein,
Table 3. The minimum inhibitory concentration of fish protein collected from Bavanisagar E. suratensis samples against pathogenic bacteria

\begin{tabular}{clc}
\hline $\begin{array}{c}\text { Sample } \\
\text { No. }\end{array}$ & $\begin{array}{c}\text { Bacterial culture } \\
\text { (inhibition zone } \text { in } \mathbf{~ m m})\end{array}$ & $\begin{array}{c}\text { Minimum inhibitory } \\
\text { concentration }(\boldsymbol{\mu g} / \mathbf{m l})\end{array}$ \\
\hline 1 & Escherichia coli & 20 \\
\hline 2 & Pseudomonas aeruginosa & 18 \\
\hline 3 & Proteus vulgaris & 15 \\
\hline 4 & Klebsiella pneumonia & 10 \\
\hline 5 & Citrobacter sp. & 20 \\
\hline 6 & Serratia marcescens & 25 \\
\hline 7 & Micrococcus sp. & 30 \\
\hline 8 & Staphylococcus aureus & 60 \\
\hline 9 & Bacillus subtilis & 45 \\
\hline
\end{tabular}

Table 4. The minimum bactericidal concentration of fish protein collected from Bavanisagar E. suratensis samples against pathogenic bacteria

\begin{tabular}{|c|c|c|c|c|c|c|c|c|c|c|}
\hline \multirow[b]{2}{*}{$\begin{array}{l}\text { Sample } \\
\text { No. }\end{array}$} & \multirow[b]{2}{*}{$\begin{array}{l}\text { Concentration of } \\
\text { extracts }(\mu \mathrm{g} / \mathrm{ml})\end{array}$} & \multicolumn{9}{|c|}{$\begin{array}{c}\text { Minimum bactericidal concentration (Optical density value) of protein isolated from } E \text {. suratensi } \\
\text { of Bavanisagar }\end{array}$} \\
\hline & & 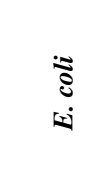 & 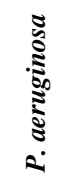 & 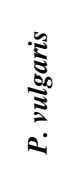 & 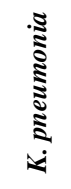 & 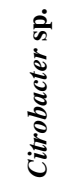 & 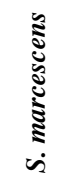 & 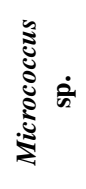 & 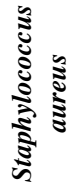 & 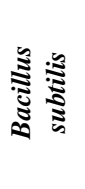 \\
\hline 1 & normal & 1.8 & 1.7 & 1.9 & 2.0 & 2.0 & 2.0 & 1.9 & 1.8 & 1.9 \\
\hline 2 & 20 & 0.8 & 0.65 & 0.85 & 0.9 & 0.65 & 0.9 & 0.8 & 0.7 & 0.85 \\
\hline 3 & 40 & 0.6 & 0.5 & 0.7 & 0.85 & 0.6 & 0.76 & 0.7 & 0.65 & 0.78 \\
\hline 4 & 60 & 0.4 & 0.4 & 0.5 & 0.62 & 0.51 & 0.63 & 0.53 & 0.56 & 0.63 \\
\hline 5 & 80 & 0.2 & 0.3 & 0.4 & 0.4 & 0.42 & 0.41 & 0.35 & 0.38 & 0.41 \\
\hline 6 & 100 & 0.1 & 0.2 & 0.1 & 0.32 & 0.2 & 0.3 & 0.1 & 0.2 & 0.2 \\
\hline 7 & streptomycin -50 & 0.34 & 0.35 & 0.4 & 0.42 & 0.16 & 0.53 & 0.52 & 0.42 & 0.35 \\
\hline 8 & streptomycin - 100 & 0.16 & 0.1 & 0.12 & 0.13 & 0.4 & 0.5 & 0.25 & 0.13 & 0.16 \\
\hline
\end{tabular}

Table 5. Antibody response in E. suratensis protein against bacterial strains

\begin{tabular}{|c|c|c|c|c|c|c|c|c|c|c|}
\hline $\begin{array}{l}\text { Sample } \\
\text { No. }\end{array}$ & $\begin{array}{l}\text { Fish sample } \\
\text { E. suratensis }\end{array}$ & $\begin{array}{l}\text { Week after } \\
\text { treatment }\end{array}$ & $\begin{array}{l}\dot{\Xi} \\
\dot{0}\end{array}$ & 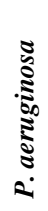 & 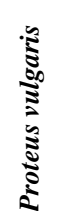 & 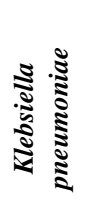 & 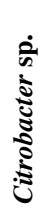 & 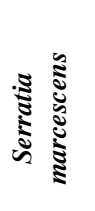 & 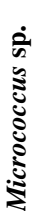 & $\begin{array}{l}\tilde{\Xi} \\
\stackrel{\Xi}{\Xi} \\
\dot{\Xi}\end{array}$ \\
\hline
\end{tabular}

\begin{tabular}{cccccccccccc}
\hline 1 & control & I & 3 & 3 & 2 & 4 & 3 & 4 & 2 & 3 & 4 \\
\hline & & II & 5 & 6 & 4 & 5 & 5 & 6 & 4 & 5 & 6 \\
\hline & III & 5 & 6 & 5 & 6 & 5 & 5 & 5 & 6 & 6 \\
\hline 2 & Bavanisagar & I & 1 & 1 & 2 & 1 & 1 & 2 & 1 & 2 & 1 \\
\hline & & II & 2 & 2 & 1 & 1 & 2 & 2 & 2 & 2 & 3 \\
\hline & III & 2 & 2 & 2 & 2 & 3 & 3 & 2 & 3 & 4 \\
\hline
\end{tabular}


Table 6. Immunoglobulin level in fish exposed to protein isolated from Bavar/Bavanisagar dam

\begin{tabular}{cccccc}
\hline Sample No. & \multirow{2}{*}{ Day } & \multicolumn{2}{c}{ Control } & \multicolumn{2}{c}{ Treated } \\
\cline { 3 - 6 } & & OD $(\mathbf{2 8 0} \mathbf{~ n m})$ & IgG level $(\mathbf{m g} / \mathbf{m l})$ & OD $(\mathbf{2 8 0} \mathbf{~} \mathbf{m})$ & IgG level $(\mathbf{m g} / \mathbf{m l})$ \\
\hline 1 & 7 & 0.258 & 3.81 & 1.00 & 14.80 \\
\hline 2 & 14 & 0.257 & 3.80 & 2.142 & 31.70 \\
\hline 3 & 21 & 1.257 & 18.60 & 2.478 & 36.67 \\
\hline 4 & 28 & 0.235 & 3.47 & 1.358 & 20.09 \\
\hline
\end{tabular}

E. suratensis, collected from Bavanisagar had a broad spectrum of antibacterial potential. The fish protein of E. suratensis samples collected from Bavanisagar (B) showed the higher MBC value against Bacillus subtilis $(0.85 / 20 \mu \mathrm{g} / \mathrm{ml})$ and the lowest value against Micrococcus $(0.1 / 100 \mu \mathrm{g} / \mathrm{ml})$. The protein of E. suratensis samples collected from Bavanisagar exhibited the highest antibacterial activity against $S$. marcescens $(1.9 / 40 \mu \mathrm{g} / \mathrm{ml})$ and the least activity against $E$. coli $(1.0 / 100 \mu \mathrm{g} / \mathrm{ml})$ (Table 4$)$.

The sub-lethal dose was estimated at $1 / 10$ of $96 \mathrm{~h} \mathrm{LD}_{50}$ dose $(30 \mu \mathrm{g} / \mathrm{ml} / \mathrm{kg})$. In both the control and the experimental groups the peak antibody response was noticed on day 21 after immunization which decreased towards day 28 (Table 5). In the protein collected from Bavanisagar treated group, the antibody response was significantly enhanced on day 14 and day $21(p<0.01)$ (Table 5). The protein of $E$. suratensis samples collected from Bavanisagar had shown significant antibody production. These results showed that the fish protein isolated from E. suratensis stimulated the antibody production against Aphanomyces invadans therefore against epizootic ulcerative syndrome.

The highest IgG level was noticed on day 21 which decreased towards day 28 . This result showed the antibody production with an increased IgG concentration. Our results proved that the antibody production increased with the increasing $\mathrm{IgG}$ production (Table 6). It has been shown that the great majority of patients suffering from fungal infections, as well as many normal, healthy individuals, develop serum IgG against fungal antigens [9]. The antibody response of $E$. suratensis against the bacterial pathogens as studied and the results are given in Table 5. In both the control and the experimental groups the peak antibody response was noticed on day 21 after immunization for all the species of bacteria. The protein of E. suratensis samples collected from Bavanisagar had shown significant antibody production. The results of the $\mathrm{IgG}$ level in fish exposed to fish protein on the $7^{\text {th }}, 14^{\text {th }}, 21^{\text {st }}$ and $28^{\text {th }}$ day is given in Table 6 . In all the fish samples, the $\mathrm{IgG}$ level was higher in the treated fish when compared to the control fish. The highest IgG level was noticed on day 21 which decreased towards day 28.

The protein sample was isolated and characterized by the western blot method. Bands in lane 4 indicate standard protein. Band in lane 1-3 indicates all the proteins pres- ent in the protein sample. The band on the NC membrane represents the protein present interacting with the primary antibody. The position of band on the membrane indicates their electrophoretic mobility during electrophoresis. All protein extracts of E. suratensis tested have exhibited various degrees of antibacterial activity against tested pathogenic microorganisms viz. E. coli, P. aeruginosa, $P$. vulgaris, K. pneumoniae, Citrobacter sp., S. marcescence, Micrococcus sp., S. aureus and B. subtilis. E. suratensis protein showed significant inhibition against $P$. aeruginos and $P$. vulgaris. The result of the present study coincides with the findings of Sujatha et al. and Alves et al. [9, 10]. They reported that the antimicrobial activity of E. suratensis extract is partially active against $P$. aeruginosa. Similar results were reported by other workers $[2,11]$. Mahesh and Satish noticed the antimicrobial activity of ethanol extract of Acacia nilotica which showed significant activity against $P$. aeruginos $a$ and least activity was recorded against E. coli [12]. Gram negative bacteria viz. E. coli, $P$. aeruginosa, $P$. vulgaris, K. pneumoniae, Citrobacter sp., S. marcescens and gram positive bacteria viz. Micrococcus sp., $S$. aureus and B. subtilis showed a reduction in their growth on treatment with the different solvent extracts of E. suratensis. Similar findings were reported by Thomas and Mccubbin and Sasikumar and Papinazath [13, 14].

The minimal inhibitory concentrations of E. suratensis against pathogens are the highest in extracts of Bavanisagar fish samples. Similar observation was noticed by Dhasarathan et al. (2011) in plant and animal extracts against pathogens. The present work clearly depicts that the Bavanisagar, E. suratensis extracts have the highest concentration $(100 \mu \mathrm{g} / \mathrm{ml})$ which effectively controls the growth of bacteria. These results partly validate the ethnobotanical use of many Combretum species for conditions that may be of bacterial etiology. $C$. woodii extracts also contain other antibacterial compounds with high antibacterial activity against Escherichia coli, Pseudomonas aeruginosa and Enterococcus faecalis. Similar results of Bhushan et al. (2008) stating that minimum bactericidal concentration was $20-80 \mu \mathrm{g} / \mathrm{ml}$ for the gram negative bacteria and $20-60 \mu \mathrm{g} / \mathrm{ml}$ against gram positive bacteria coincide with our present study [15]. 
Fish protein extract modulated the body weight comparing with that of normal E. suratensis; some notable changes were also noted in growth, water consumption, feed consumption, and reproduction. It also modulated the host animals for immune enhancement. Fish injected with the Aphanomyces invadans showed lesions occasionally near the tail and on the opercula of infected fish. Fish injected with sterilized water did not develop lesions and no significant pathological signs were observed. The similar findings were also observed by Dhasarathan et al. in freshwater tropical fish [7]. The current work also showed that Aphanomyces invadans is the major causative agent of epizootic ulcerative syndrome. Aeromonas hydrophila is generally considered to be a secondary invader in red sore disease, in which the primary etiological agent was believed to be the fungus Aphanomyces invadans [4].

From the above results it can be concluded that fish protein extracts have great potential as immunostimulants against the microorganisms and they can be used in the treatment of infectious diseases caused by the microorganisms. This protein may be used to discover bioactive natural products that may serve as a lead for the development of new pharmaceuticals.

Authors declare no conflict of interest.

\section{References}

1. Silphaduang U, Noga EJ (2001): Peptide antibiotics in mast cells of fish. Nature 414: 268-269.

2. Manjula SN, Bharath EN, Divya B (2011): Medicinal and biological significance of quinazoline: a highly important scaffold for drug discovery: A review. Int J Pharma Bio Sci 2: 780-809.

3. Paulsi S, Dhasarathan P (2011): Estimation of biochemical status and immunostimulant potential of chosen fruits. Int J Pharma Biosciences 2: B90-97.

4. Haniffa MA, Dhanuskodi V, Dhasarathan P (2011): Evaluation of immunostimulant potential of Solanum nigrum L. using fish, Etroplus suratensis challenged with Aphanomyces invadens. Int J Pharma Bio Sciences 2: B429-B437.

5. Samy PR, Ignacimuthu M (2001): Antibacterial extracts of the bark of Terminalia arjuna justification of Folklare belief. Pharmaceutical Biol 39: 417-420.

6. Geetha VV, Balamurugan P, Bhaskaran M (2011): Characterization of mustard genotypes through image analysis. Res J Seed Sci 4: 192-198.

7. Dhasarathan P, Haniffa MA, Geetha K, Dhanushkodi V (2011): Impact of climatic change on microbial population of Tamirabarani river. Asian J Microbiol Biotech Env Sci 13: 56-59.

8. Dhasarathan P, Premalatha M, Syed Ali Fathima K, Meenakshi V (2010): Screening the anticancerous efficacy of Tamarindus indica $\mathrm{L}$. Using mineral oil induced swiss albino mice. Asian J Microbiol Biotech Env Sci 12: 1-4.

9. Sujatha M, Karthick B, Dhasarathan P (2010): Antibiotic susceptibility and immunomodulatory potential of chosen bacterial pathogens. Am J Immunol 6: 15-19.
10. Alves AL (2000): Análise daa evoluçăo dos gęneros da subfamília mipsilichthiinae (Ostariophysi, Siluriformes, Loricariidae) com base em caracteres cromossômicose de DNA mitocondrial. Master's thesis, Universidade Estadual Paulista, Botucatu.

11. Dharmananda S (2003): Gallnuts and the uses of Tannins in Chinese Medicine. In: Proceedings of Institute for Traditional Medicine, Portland, Oregon. Dietary vitamin C and glucan in rainbow trout (Oncorhynchus mykiss). Fish Shell Immunol 8: 409-424.

12. Mahesh B, Satish S (2008): Antimicrobial activity of some important medicinal plant against plant and human pathogens. World J Agri Sci 4 (S): 839-843.

13. Thomas S, McCubbin P (2003): A comparison of the antimicrobial effects of four silver-containing dressings on three organisms. J Wound Care 12: 101-107.

14. Sasikumar CS, Papinazath T (2003): Environmental management: bioremediation of polluted environment. In: Bunch MJ, Suresh VM, Kumaran TV (eds.). Proceedings of the Third International Conference on Environment and Health, Chennai, India, 15-17 December, Chennai: Department of Geography, University of Madras and Faculty of Environmental Studies, York University, pp. 465-469.

15. Bhushan I, Parshad R, Qazi GN, et al. (2008): Lipase enzyme immobilization on synthetic beaded macroporous copolymers for kinetic resolution of chiral drugs intermediate. Process Biochem 43: 321-330. 